\title{
FECUNDITY OF BLUE SWIMMING CRAB, Portunus pelagicus LINNAEUS, 1758 FROM SEMATAN FISHING DISTRICT, SARAWAK COASTAL WATER OF SOUTH CHINA SEA
}

\author{
IKHWANUDDIN ABDULLAH @ POLITY. ${ }^{1 *}$, JUARIAH HAFSYA MUHAMAD ${ }^{1}$, \\ SHABDIN MOHD LONG ${ }^{2} \&$ ABOL-MUNAFI AMBOK BOLONG ${ }^{1}$
}

\author{
${ }^{1}$ Institute of Tropical Aquaculture, Universiti Malaysia Terengganu, 21030 Kuala Terengganu, \\ Terengganu; ${ }^{2}$ Faculty of Science and Resource Technology, Universiti Malaysia Sarawak, \\ 94300 Kota Samarahan, Sarawak.
}

\begin{abstract}
A total of 57 pieces of ovigerous females were sampled through the study period of 14 months from the commercial catches that were made at the Sematan Fishing District, Sarawak coastal water. These ovigerous females were used to determine the crab fecundity through mean number of egg per crab. The present study shows that the mean number of egg is 2,132,924 with mean egg size (volume) $9.3 \times 10-6 \mathrm{ml}$ and mean egg size (diameter) $383.6 \mu \mathrm{m}$ measured using volumetric sub sampling. Fecundity was significantly related to crab size with larger crabs producing a greater number of eggs through linear regression of the fecundity - carapace width relationship. The fecundity-carapace width relationship for $P$. pelagicus was estimated as follows; $y=106804 x+375319(\mathrm{R} 2=0.0229 ; \mathrm{n}=57)$. The study shows that the egg size is significantly larger $(\mathrm{P}<0.05)$ as the eggs nearly about to hatch which is black in colour
\end{abstract}

Key words: Fecundity, blue swimming crab, Portunus pelagicus

\section{INTRODUCTION}

The blue swimming crab, Portunus pelagicus Linnaeus, 1758 is distributed throughout the Indopacific region and is closely associated with sheltered near-shore marine water and estuaries (Stephenson 1962; Kailola et al. 1993). Studies showed that large numbers of portunid crabs including $P$. pelagicus frequently enter estuaries as juveniles and remain there for an extended period (Hill, 1975; Potter et al., 1983; Perkins-Visser et al. 1996; Potter \& de Lestang, 2000). Studies showed that female portunid crabs including $P$. pelagicus sometimes become ovigerous in estuaries; such individuals emigrate into coastal marine water, where they release their eggs (Van Engel, 1958; Metcalf et al., 1995; Potter \& de Lestang 2000). Other studies also show that portunid crabs that occupy marine embayment often do not leave these marine environments to spawn and, in cases where there is a salinity gradient, they spawn in the high salinity regions of those systems (Campbell, 1984;

*Corresponding author: ikhwanuddin@umt.edu.my
Sumpton et al., 1994; Prager, 1996; Potter \& de Lestang 2000).

The fecundity of fish is defined as the number of ripening eggs in the female prior to the next spawning period (Bagenal 1978). In portunid crabs the ripening egg mass was referred as 'berry' eggs contained a variable number of eggs depending on the size of the individual and the size of the berry (Pillay \& Nair 1968). The number of eggs produced by females also varies between individuals of a similar size. Generally, larger females produce more eggs than smaller females (Warner 1977; Batoy et al. 1987; de Lestang et al. 2003a). Studies also show female crabs can produce two or more batches of eggs within a spawning period (Meagher 1971; de Lestang et al. 2003a).

Studies on the reproductive biology of Portunus spp. has been mostly conducted in Australia (Potter et al. 1983; Sumpton et al. 1994; Sumpton 2001; de Lestang et al. 2003a; de Lestang et al. 2003b; Kumar et al. 2003) and a few studies from other 
countries within the Indo-Pacific region such as India (Pillay \& Nair 1971), Philippines (Batoy et al. 1987) and Taiwan (Lee \& Hsu, 2003). Despite the high fishery potential of $P$. pelagicus in Malaysia, literature reviews show that no study has been done on the reproductive biology of this species of crab in any water bodies of Malaysia. The present study was conducted to determine the fecundity of $P$. pelagicus through mean number of egg per crab.

\section{MATERIALS AND METHODS}

The study was done within the shallow coastal water of the commercial fishing grounds for P. pelagicus of the Sematan Fishing District, which is located at the most western part of Sarawak, Malaysia stretching from Tanjung Dato to Sampadi. This shallow coastal water is within Talang-talang Island, centering at $1^{\circ} 53^{\prime} \mathrm{N}, 109^{\circ} 48^{\prime} \mathrm{E}$.

A total of 57 ovigerous female crabs were sampled throughout the study period of 14 months from 14 fishing trips of the commercial catches. These ovigerous females were used for the determination of the crab fecundity. The samples were measured for carapace width and body weight. Carapace is measured as the external carapace width, which is the distance between the tips of 9th antero-lateral spines of the carapace. The carapace width is measured to the nearest $0.1 \mathrm{~cm}$ with vernier callipers. The vernier callipers unit model is Kernn Germany $(150 \times 0.05 \mathrm{~mm})$, produced by Kernn Germany, Germany. Body weight of the crab is measured to the nearest gram by using a digital electronic balance of $0.1 \mathrm{gm}$ sensitivity. The digital electronic balance unit model is DJ-6000P, produced by Shinko Denshi Co., Ltd., Japan.

The ovigerous females were then killed and the fresh eggs were stripped off from the broad abdomen of the crab pleopod. The weight of the stripped egg mass was also measured. The egg mass was washed with fresh water before being preserved in labelled 50 litres glass jars containing modified Gilson's fluid for counting later (Simpson 1951). This preservative has been used by many investigators and has been found to act satisfactorily with a wide range of species (Bagenal 1978). This preservative was prepared as follows; $100 \mathrm{ml}$ of $60 \%$ alcohol, $880 \mathrm{ml}$ of water, $15 \mathrm{ml}$ of $80 \%$ nitric acid, $18 \mathrm{ml}$ of glacial acetic acid and $20 \mathrm{gm}$ of mercuric chloride.

The preserved egg mass was shaken vigorously and left for $24 \mathrm{hr}$ after which, repeated shaking was done to help separate the eggs from egg tissues and assist the penetration of the preservative (Bagenal 1978). The egg mass was preserved for 3 months (Ikhwanuddin 2001). After three months the preserved egg mass was washed with water before enumeration using volumetric sub sampling (Bagenal 1978) as follows: The cleaned eggs were poured into a $250 \mathrm{ml}$ measuring cylinder in which they soon settled down (Kandler \& Pirwitz 1957). The total volume of eggs was noted. One $\mathrm{ml}$ of eggs volume was then removed and transferred into a 100 $\mathrm{ml}$ measuring cylinder containing $99 \mathrm{ml}$ volume of water to mark-up the volume to $100 \mathrm{ml}$. For the purpose of egg counting, one $\mathrm{ml}$ of the egg suspension was drawn out using a $3 \mathrm{~mm}$ diameter feeding tube attached to a $10 \mathrm{ml}$ syringe. During sucking, the egg suspensions were shaken and stirred using glass rod to make sure they were well dispersed. The fecundity was estimated as the mean of five counts.

\section{RESULTS}

The fecundity parameters of the female crab included crab carapace width $(\mathrm{CW})$, number of egg per crab and crab egg size (volume and diameter). The mean number of egg was 2,132,924 $\pm 723,956$ with mean egg size (volume) $9.3 \times 10-6 \pm 4.7 \times 10-6$ $\mathrm{ml}$ and mean egg size (diameter) $383.6 \pm 102.3 \mu \mathrm{m}$ (Table 1). Fecundity was significantly related to crab size with larger crabs producing a greater number of eggs. The fecundity-carapace width relationship of linear regression for $P$. pelagicus was estimated as follows; $y=106804 x+375319$ (R2=0.0229; n=57) (Figure 1).

Generally there were three colours of the crab egg sampled, yellow-orange, brown and black (Table 2). Newly laid eggs were yellow-orange in colour and nearly hatched eggs were black in colour. The study shows that the mean egg size (diameter) were 390.3 $\mu \mathrm{m}, 383.2 \mu \mathrm{m}$ and $373.4 \mu \mathrm{m}$ for egg colour of black, brown and yellow-orange, respectively (Table 2). This study shows that the egg size was significantly larger as the eggs were about to hatch which is black in colour $(\mathrm{P}<0.05)$.

\section{DISCUSSION}

To the best of the authors' knowledge, there has been no comparable data in the literature on the 
reproductive biology of Portunus spp. in Malaysia available. Table 3 shows a summary of available data on the fecundity of $P$. pelagicus from other studies by de Lestang et al. (2003a), Batoy et al. (1987) and Potter et al. (1983).

The number of eggs produced per ovulation in the present study is very large and varies with the size of the crab and between females. The trend was observed in the present study where larger crabs with larger carapace width produce more eggs than smaller ones with smaller carapace width, the same trend has been suggested by Warner (1977). This trend has also been described by other researchers such as de Lestang et al, . (2003), Potter et al. (1983) and Batoy et al. (1987) (Table 3). Additionally,

Table 1. Mean, maximum, minimum and standard deviation $(\mathrm{Sd})$ values for the fecundity parameters of the female crab of P. pelagicus

\begin{tabular}{ccccc}
\hline & \multirow{2}{*}{ CW $(\mathrm{cm})$} & No. of egg per crab & \multicolumn{2}{c}{ Egg size } \\
& & & Egg volume $(\mathrm{ml})$ & Egg diameter $(\mu \mathrm{m})$ \\
\hline Mean & 16.5 & $2,132,924.0$ & $9.3 \times 10-6$ & 383.6 \\
Max & 19.3 & $3,376,666.7$ & $2.4 \times 10-5$ & 633.1 \\
Min & 14.4 & $213,333.3$ & $1.9 \times 10-6$ & 179.9 \\
Sd & 1.0 & $723,956.0$ & $4.7 \times 10-6$ & 102.3 \\
\hline
\end{tabular}

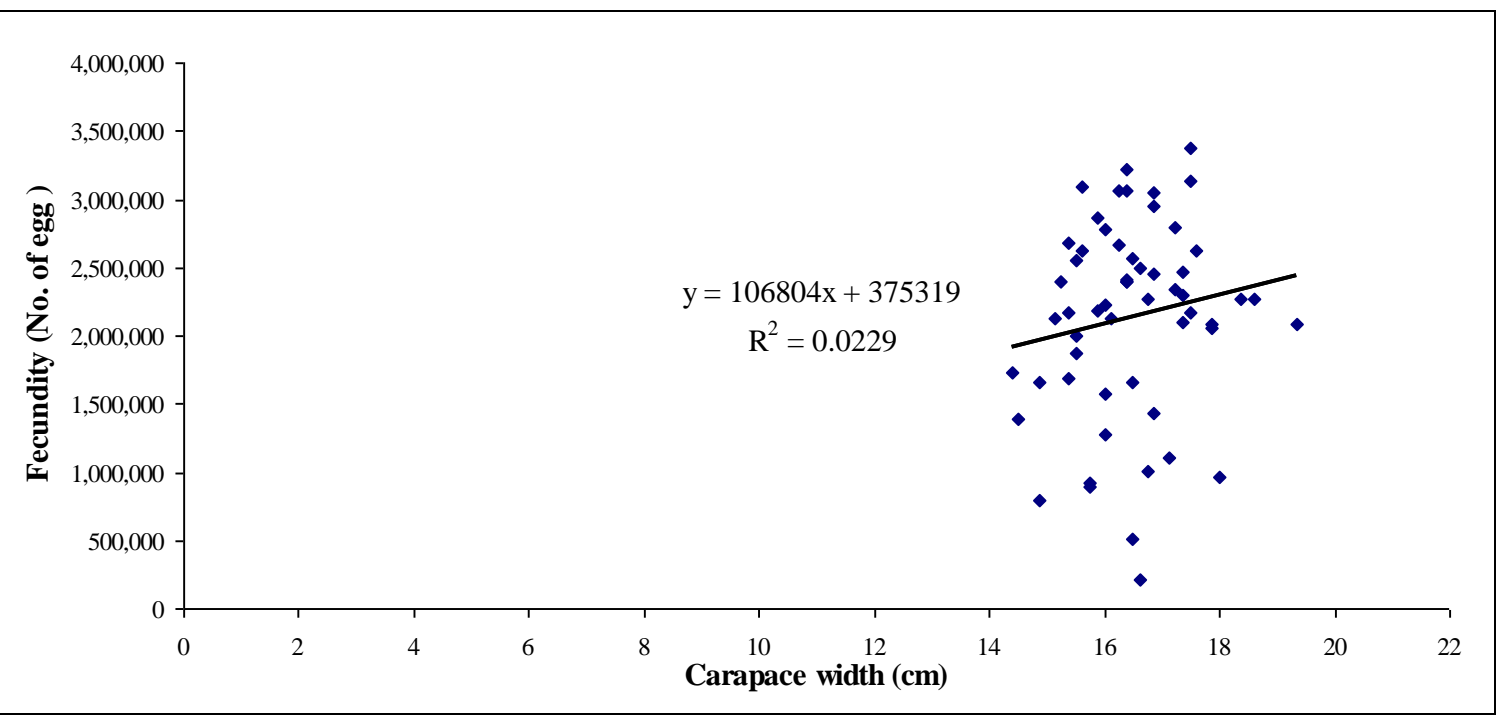

Figure 1. Relationship between crab fecundity and crab carapace width for P. Pelagicus.

Table 2. Egg colourations and size (diameter) of $P$. pelagicus

\begin{tabular}{lcccc}
\hline \multirow{2}{*}{ Egg colour } & \multicolumn{3}{c}{ Egg size (diameter, $\mu \mathrm{m})$} & Samples number $(\mathrm{n})$ \\
\cline { 2 - 4 } & Mean & Maximum & Minimum & 27 \\
\hline Black & 390.3 & 633.1 & 202.6 & 13 \\
Brown & 383.2 & 538.4 & 266.8 & 17 \\
Yellow-orange & 373.4 & 522.0 & 179.9 & 17 \\
\hline
\end{tabular}


report by Kumar et al. (2003) has revealed that fecundity increased $83.9 \%$ with an increase of carapace width from 10.5 to $12.5 \mathrm{~cm}$. The later study also shows that fecundity of female $P$. pelagicus initially increased with carapace width, reaches maximum at a carapace width of $13.4 \mathrm{~cm}$, and decreased thereafter. The present study also show that size and fecundity in female $P$. pelagicus are directly related only up to $16-17 \mathrm{~cm} \mathrm{CW}$ where the mean $\mathrm{CW}$ of ovigerous female crabs sampled are $16.5 \mathrm{~cm}$ (Table 1).

The fecundity estimate of crabs presented in the current study is comparatively higher than the other studies as in Table 3. It was also noted that all the ovigerous female crab specimens of the other studies were taken from either an estuary or a bay with wide seasonal fluctuations in temperature and salinity as compared to the present study with water temperature, $28-30^{\circ} \mathrm{C}$ and water salinity, $28-31 \mathrm{ppt}$ (Potter et al. 1983; Batoy et al. 1987; de Lestang et al. 2003a; de Lestang et al. 2003b; de Lestang et al. 2003c; Ikhwanuddinb 2007). This might have affected the reproductive capacity of $P$. pelagicus from the estuary and bay as study by Potter et al. (1983) provided strong evidence that these crabs prefer higher salinities between 30-40 ppt.

This explanation is consistent with the results of other studies, which have shown that water temperature influences ovulation and egg development in $P$. pelagicus and other decapods where the higher water temperature will fasten the ovulation and egg development period (Rahaman 1980; Campbell 1984; Pollock 1995; de Lestang et al. 2003a; Kumar et al. 2003). However, the ovigerous female crab specimens of the present study were taken from the shallow coastal water within Talang-talang Island, which is about $10.5 \mathrm{~km}$ from Sematan estuary. The shallow coastal water within Talang-talang Island did not shows wide seasonal fluctuations in temperature and salinity as compared to the other studies mention earlier. The fecundity value of the present study is higher than the other studies as mentioned earlier because the present study site does not experience any wide seasonal fluctuation in temperature and salinity (Ikhwanuddin 2007).

Table 3. Fecundity estimate of $P$. pelagicus from various studies

\begin{tabular}{|c|c|c|c|c|c|}
\hline \multirow{2}{*}{ Locality } & \multicolumn{2}{|c|}{$\mathrm{CW}(\mathrm{cm})$} & \multicolumn{2}{|c|}{ Fecundity (No. of egg / crab) } & \multirow{2}{*}{ _Source } \\
\hline & Mean & Range & Mean & Range & \\
\hline $\begin{array}{l}\text { Sarawak, } \\
\text { Malaysia }\end{array}$ & 16.5 & $14.4-19.3$ & $2,132,924$ & $213,333-3,376,666$ & Present study \\
\hline Western Australia & 11.9 & $8.4-15.4$ & 196,445 & $68,450-324,440$ & $\begin{array}{l}\text { de Lestang et al. } \\
\text { (2003a) }\end{array}$ \\
\hline Western Australia & 11.9 & $10.2-13.6$ & 509,433 & $270,183-847,980$ & Potter et al. (1983) \\
\hline $\begin{array}{l}\text { Leyte \& Bohol, } \\
\text { Philippines }\end{array}$ & 5.55 & 4.1-7.0 & 894,284 & $420,976-1,312,238$ & Batoy et al. (1987) \\
\hline
\end{tabular}

The colour and size of the crab eggs may well indicate its 'age'. As the embryos develop, the colour of the eggs change through yellow-orange to brown and from brown to black as the egg yolk was used up. The eggs swell as they develop and nearly double their newly laid volume by the time they are ready to hatch (Batoy et a., 1987). The mean diameter of the egg in the present study also support this observation with the older eggs are significantly larger than the newly laid eggs.

\section{ACKNOWLEDGEMENTS}

The authors would like to thank the Inland Fisheries, Agriculture Department, Sarawak for their financial support, the Faculty of Resource Science \& Technology, University Malaysia Sarawak for their 
technical support and, Mr. Mohd. Razali Kee, Mr. Aken Jetom and members of Sematan Fisheries Centre, Agriculture Department, Sarawak for assisting in the laboratory and field works.

\section{REFERENCES}

Bagenal, T.B. (1978). Part 1, Fecundity, Chapter 7, Eggs and early life History. In Methods for Assessment of Fish Production in Freshwater (Bagenal, T., ed.). IBP Handbook No.3, Third edition. London : Blackwell scientific publication. pp 166-178.

Batoy, C.B., Camargo, J.F. \& Pilapil, B.C., (1987). Breeding season, sexual maturity and fecundity of the blue crab, Portunus pelagicus $(L)$ in selected coastal waters in Lye and vicinity, Philippines. Annals of Tropical Research, 9: 157-177.

Campbell, G.R. (1984). A comparative study of adult sexual behavior and larval ecology of three commercially important portunid crabs from the Moreton Bay region of Queensland, Australia. Ph.D. thesis. Australia : University of Queensland. p 253.

de Lestang, S., Hall, N.G \& Potter, I.C. (2003a). Reproductive biology of the blue swimmer crab (Portunus pelagicus, Decapoda: Portunidae) in five bodies of water on the west coast of Australia. Fishery Bulletin, 101:745-757.

de Lestang, S., Hall, N.G \& Potter, I.C. (2003b). Influence of a deep artificial entrance channel on the biological characteristics of the blue swimmer crab Portunus pelagicus in a large microtidal estuary. Journal of Experimental Marine Biology and Ecology, 295: 41-61.

de Lestang, S., Hall, N.G \& Potter, I.C. (2003c). Do the age compositions and growth of the crab Portunus pelagicus in marine embayments and estuaries differ? Journal of the Marine Biological Association of the United Kingdom, 83:971-978.

Hill, B.J. (1975). Abundance, breeding and growth of the crab Scylla serrata in two South African estuaries. Marine Biology, 32:119-126.

Ikhwanuddin, A.M. (2001). The Biology and Fishery of Mud Crab, genus Scylla in East Malaysia. M.Sc. thesis. Faculty of Resource Science and Technology. Malaysia : Universiti Malaysia Sarawak. p 213.
Ikhwanuddin, A.M. (2007). The biology, fishery and the development of seed production technology of blue swimming crab, Portunus pelagicus (Linnaeus, 1758). Ph.D. thesis, Faculty of Resource Science and Technology. Malaysia : Universiti Malaysia Sarawak. p 411.

Kailola, P.J., Williams, M.J., Stewart, P.C., Riechelt, R.E., McNee, A. \& Grieve, C. (1993). Australian Fisheries Resources. Canberra, Bureau of Resources Sciences.

Kandler, R. \& Pirwitz, W. (1957). Uber die Fruchtbarkeit der Plattfische im Nordsee-OstseeRaum. Kieler Meeresforsch, 13:11-34.

Kumar, M.S., Xiao, Y., Venema, S. \& Hooper, G (2003). Reproductive cycle of the blue swimmer crab, Portunus pelagicus, off southem Australia. Journal of Marine Biological Association of the United Kingdom, 83:983-994.

Lee, H.H. \& Hsu, C.C. (2003). Population biology of the swimming crab, Portunus sanguinolentus in the waters off northern Taiwan. Journal of Crustacean Biology, 23:691-699.

Meagher, T.D. (1971). Ecology of the crab Portunus pelagicus (Crustacea: Portunidae) in south western Australia. Ph.D. thesis. Perth : University of Western Australia. p 227.

Metcalf, K.S., van Montfrans, J., Lipcius, R.N. \& Orth, R.J. (1995). Settlement indices for blue crab megalopae in the York River, Virginia: temporal relationships and statistical efficiency. Bulletin of Marine Science, 57:781-792.

Perkins-Visser, E., Wolcott, T.G \& Wolcott, D.L. (1996). Nursery role of seagrass beds: enhanced growth of juvenile blue crabs (Callinectes sapidus Rathburn). Journal of Experimental Marine Biology and Ecology, 198:155-171.

Pillay, K.K. \& Nair, N.B. (1968). Observation on breeding biology of some crabs from the southwest coast of India. Journal of Marine Biological Association of India, 15:754-770.

Pillay, K.K. \& Nair, N.B. (1971). The annual reproductive cycles of Uca annulipes, Portunus pelagicus and Metapenaeus affinis (Decapoda: Crustacea) from the south west coast of India. Marine Biology, 11:152-166.

Pollock, D.E. (1995). Changes in maturation ages and sizes in crustacean and fish population. South African Journal of Marine Science, 15:99-103. 
Potter I.C. \& de Lestang S. (2000). Blue swimmer crab Portunus pelagicus in Leschenault Estuary and Koombana Bay, south-western Australia. Journal of the Royal Society of Western Australia, 83:443-458.

Potter, I.C., Chrystal, P.J. \& Loneragan, N.R. (1983). The biology of the blue manna crab, Portunus pelagicus on an Australian estuary. Marine Biology, 78:75-85.

Prager, M.H. (1996). A simple model of the blue crab, Callinectes sapidus spawning migration in Chesapeake Bay. Bulletin of Marine Science, 58:421-428.

Rahaman, A.A. (1980). Ecological observations on spawning of a few invertebrates of the Madras coast. Journal of Madurai Kamaraj University, 9:71-77.

Stephenson, W. (1962). The evolution and ecology of portunid crabs, with special reference to Australian species. In The evolution of living organisms (Leeper, GW., ed.). Melbourne
Melbourne University Press. pp 34-67.

Simpson, A. C. (1951). The fecundity of the plaice. Fishery Investment London, Series 2, 17, No5, $22 \mathrm{pp}$.

Sumpton, W.D. (2001). Fisheries biology and assessment of the blue swimming crab (Portunus pelagicus) in Queensland. Fisheries Research Development Corporation, Department of Primary Industries Queensland, Project No. 98/117.

Sumpton, W.D., Potter, M.A. \& Smith, G.S. (1994). Reproduction and growth of the commercial sand crab, Portunus pelagicus (L.) in Moreton Bay, Queensland. Asian Fisheries Science, 7:103-113.

Van Engel, W.A. (1958). The blue crab and its fishery in Chesapeake Bay. Part 1. Reproduction, early development, growth and migration. Commercial Fisheries Review, 20:6-17.

Warner, G.F. (1977). The biology of crabs. London : Paul Elek (Scientific Books). p 202. 